\title{
確率過程論による静定構造物の信頼性解析* \\ RELIABILITY ANALYSIS OF STATICALLY DETERMINATE STRUCTURES WITH THEORY OF STOCHASTIC PROCESSES
}

\author{
白木 渡** - 高岡 宣 善*** \\ By Wataru SHIRAKI and Nobuyoshi TAKAOKA
}

\section{1.まえがき}

構造物に作用する荷重ならびにその部材強度は，構造 物の耐用期間中に時間に関して不規則に変動する確率過 程である.それゆえに，構造物の信頼性の正しい解は， 確率過程論の助けをかりて初めて求められる. 確率過程 論を用いた構造物の信頼性に関する研究は, 単一部材に 単一荷重が作用する場合については，三，三発表されて いる(1) 3). しかしながら, 構造物は, 通常多数の部材要 素からなり，種々の荷重条件を受けるのが普通であるか ら, 構造物を安全に設計するためには, 構造物を構成す る全部材およびそれに作用する全荷重条件を考慮した構 造系全体の信頼性解析を確率過程論を用いて行う必要が ある。

以上のような観点から, 本論文では荷重および部材強 度をともに確率過程と考えた場合の多部材要素からなる 構造物の信頼性解析を確率過程論を用いて行った。構造 モデルとしては, 任意の部材のいずれかが破壊しても構 造系の破壊につながる静定構造物のような“weakestlink” モデルを考えて, まず互いに統計的に独立な $m$ 個 の荷重を受ける $n$ 部材要素からなる静定構造物で, 荷重 および部材強度がともに任意の確率分布を有する確率過 程であるような一般的な場合の破壊確率の算定式の誘導 を, 多次元空間の場合の超過の理論 ${ }^{4)}$ を用いて行った. 次に部材強度および部材力がともに正規定常確率過程 で, 各部材の破壊事象の間の相関関係を考慮した場合の $n$ 部材静定トラスに適用できる多次元式を示した. そし て,この一般式の適用方法を具体的に示すために，3部 材からなる静定トラスを取りあげ, 数值計算を行った.

数值計算は, 部材強度が正規確率変数である $n$ 部材静

* 鳥取大学工学部研究報告, 第 6 巻第 1 号, pp. 81-92, 1976 年 3 月および昭和 51 年度土木学会中国四国支部年次学術 講演会, I -6 で一部発表.

** 正会員 工修 鳥取大学助手 工学部土木工学科

*** 正会員 工博 鳥取大学教授 工学部土木工学科
定トラスに正規定常確率過程である単一荷重が作用する 場合および部材強度が正規確率変数である 3 部材静定卜 ラスに正規定常確率過程である 2 つの統計的に独立な荷 重が作用する場合について行い, 構造物の耐用期間, 部 材強度抢よび荷重の変動係数, 部材の中央安全率および 各部材の破壊事象間の相関係数などの構造系全体の破壊 確率におよぼす影響を明らかにすることによって，本論 文で示すような確率過程論に基づく構造物の信頼性解析 の必要性を強調した。

\section{2. 一般的な場合の破壊確率の算定}

Fig. 1 に示すような“weakest-link” モデルタイプ の $n$ 部材静定トラスに任意の分布を有する互いに統計的 に独立な確率過程である $m$ 個の荷重 $S_{j}(t)(j=1,2, \cdots$, $m$ ）が準静的に同時に作用し続ける場合を考える. 一般 性をそこなうことなしに $S_{j}(t)>0$ と仮定する.荷重が 準静的に作用する確率過程であるから, 各部材の部材力 $X_{i}(t)(i=1,2, \cdots, n)$ は静力学の構造解析より求めるこ とができ，それらもまた確率過程である。また構造物の 各部材強度 $R_{i}(t)(i=1,2, \cdots, n)$ も耐用期間中に,物理 的・化学的・その他の作用を受けるので時間的にランダ ムに変動する確率過程であるとする.この場合, 老朽化 ならびに強化（二負の老朽化）現象のいずれもが生じう る叮能性がある。そして $R_{i}(t)$ の分布は, 引張りも 生縮も同じであると仮定す る.

Fig. 1 に示されるよう な静定構造系の破壊の確率 は, 部材 $i$ の破壊の 事象 $E_{i}$ を用いて,

$P_{f}(t)=\mathbf{P}\left(E_{1} \cup E_{2} \cup\right.$ $\left.\cdots \cup E_{n}\right)$

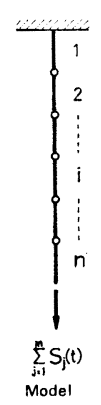

Fig. 1 Weakest-Link (1)

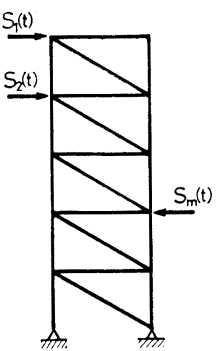

Structure System 
で与えられる。ここに，一般に $\mathbf{P}(E)$ は，事象 $E の$ 生 起する確率を意味する. 式 (1) より静定構造系の破壊 とは, 少なくとも 1 部材以上において, 不等式 $X_{i}(t)>$ $R_{i}(t)$ が成立することである. したがって，「強度の余 裕」とよばれる補助的な確率過程

$$
Z_{i}(t)=R_{i}(t)-X_{i}(t) \quad(i=1,2, \cdots, n) \cdots \cdots(2)
$$

孛成分に持つ $n$ 次元ランダムベクトル

$$
\boldsymbol{Z}(t)=\left(Z_{1}(t), Z_{2}(t), \cdots, Z_{n}(t)\right)
$$

を導入すると, 系の破壊の事象を考えることは, $n$ 次元 空間でのランダムベクトル $\boldsymbol{Z}(t)$ の正領域から負領域へ の超過の問題を考えることになる.

ここで, 成分 $Z_{i}(t)$ の特性值は, 確率過程 $X_{i}(t)$ お
よび $R_{i}(t)$ の特性值が既利であれれば谷易に決定できる。 いま，荷重は構造系に対して統計的に独立である場合芯 考えて, $X_{i}(t)$ と $R_{i}(t)$ との間には相関関係がないも のとすれば, $Z_{i}(t)$ の期待值, 相関関数および分散は, それぞれ次のようになる。

$$
\left.\begin{array}{l}
\bar{z}_{i}(t)=\bar{r}_{i}(t)-\bar{x}_{i}(t), \\
K_{z_{i}}\left(t_{1}, t_{2}\right)=K_{r_{i}}\left(t_{1}, t_{2}\right)+K_{x_{i}}\left(t_{1}, t_{2}\right), \\
\sigma_{z_{i}}{ }^{2}(t)=\sigma_{r_{i}}{ }^{2}(t)+\sigma_{x_{i}}{ }^{2}(t) .
\end{array}\right\}
$$

$n$ 次元空間でのランダムベクトル $\boldsymbol{Z}(t)$ の正領域から 負領域への超過確率の時間密度 $p_{-}(\mathbf{0} \mid t)$ は, 多次元空間 の場合の超過の理論4) を用いると, 次のように表わされ る (付録 参照).

$$
\begin{aligned}
p_{-}(\mathbf{0} \mid t)= & -\left[\int_{0}^{\infty} \cdots \int_{0}^{\infty} d z_{2} d z_{3} \cdots d z_{n} \int_{-\infty}^{\infty} \cdots \int_{-\infty}^{\infty} d \dot{z}_{2} d \dot{z}_{3} \cdots d \dot{z}_{n} \int_{-\infty}^{\infty} f\left(0, z_{2}, z_{3}, \cdots, z_{n}, \dot{z}_{1}, \dot{z}_{2}, \cdots, \dot{z}_{n} \mid t\right) \dot{z}_{1} d \dot{z}_{1}\right. \\
& +\int_{0}^{\infty} \cdots \int_{0}^{\infty} d z_{1} d z_{3} \cdots d z_{n} \int_{-\infty}^{\infty} \cdots \int_{-\infty}^{\infty} d \dot{z}_{1} d \dot{z}_{3} \cdots d \dot{z}_{n} \int_{-\infty}^{\infty} f\left(z_{1}, 0, z_{3}, \cdots, z_{n}, \dot{z}_{1}, \dot{z}_{2}, \cdots, \dot{z}_{n} \mid t\right) \dot{z}_{2} d \dot{z}_{2}+\cdots \\
& \left.+\int_{0}^{\infty} \cdots \int_{0}^{\infty} d z_{1} d z_{2} \cdots d z_{n-1} \int_{-\infty}^{\infty} \ldots \int_{-\infty}^{\infty} d \dot{z}_{1} d \dot{z}_{2} \cdots d \dot{z}_{n-1} \int_{-\infty}^{\infty} f\left(z_{1}, z_{2}, \cdots, z_{n-1}, 0, \dot{z}_{1}, \dot{z}_{2}, \cdots, \dot{z}_{n} \mid t\right) \dot{z}_{n} d \dot{z}_{n}\right]
\end{aligned}
$$

ここに, $f\left(z_{1}, z_{2}, \cdots, z_{n}, \dot{z}_{1}, \dot{z}_{2}, \cdots, \dot{z}_{n}\right)$ は, 与えられ た同一侍点に扩ける $\boldsymbol{Z}(t)$ とその導関数

$$
\dot{\boldsymbol{Z}}(t)=\frac{d \boldsymbol{Z}(t)}{d t}=\frac{d \boldsymbol{R}(t)}{d t}-\frac{d \boldsymbol{X}(t)}{d t}
$$

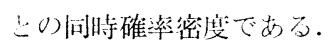

一般に，構造物が十分な炎全性を有するためには，㨦 度:の余裕 $Z_{i}(t)$ の期街值 $\bar{z}_{i}(t)$ は $z_{i}=0$ より十分大き く離れた正の值であり, ゼロから負領域への超過がまれ な事象となるものでなければならない，したがって，そ のような場合を考えると, ランダムべクトル $\boldsymbol{Z}(t)$ の僨 領域への各超過は, ポアンン過程で近似できるので, 式 (1) で示される構造系の破壊確率 $P_{f}(t)$ は, 式 (4) で 表わされる超過確率の時間密度 $p_{-}(\mathbf{0} \mid t)$ を用いて, 次 式で表わされる.

$$
P_{f}(t)=1-\exp \left[-\int_{0}^{t} p_{-}(\mathbf{0} \mid t) d t\right]
$$

この $P_{f}(t)$ という值は, 時間が $t$ だけ経過する閒に ランダムベクトル $\boldsymbol{Z}(t)$ のうち少なくとも 1 つの成分が 少なくとも 1 回ゼロの值を負交差する確率を表わしてい る.

しかし, 耐朋期間 $t \circlearrowright$ 間にランダムベクトル $\boldsymbol{Z}(t)$ が 限界值 0 を超過するために生ずる構造物の破壊の全確率 は $P_{f}(t)$ ではない. 全確率は, この上さらに「載荷の 最初の時点 $t=0$ において $\boldsymbol{Z}(t)$ が 0 といら值を超過す る, すなわち構造物が最初から破壊する」といら事象の 確率を加えなければならない。この確率は,

$$
F_{\boldsymbol{z}}(\mathbf{0})=1-\int_{0}^{\infty} \cdots \int_{0}^{\infty} f_{\boldsymbol{z}}\left(z_{1}, z_{2}, \cdots, z_{n}\right) d z_{1} d z_{2} \cdots d z_{n}
$$

で表わされる.ここに, $f_{\boldsymbol{z}}\left(z_{1}, z_{2}, \cdots, z_{n}\right)$ は, $\iota=0$ で のランダムベクトル $\boldsymbol{Z}(\ell)$ の確率密度関数である.

したがって, 期間 $\iota$ における構造物の破鉬の全確率 $\hat{P}_{f}(t)$ は，次のよらになる.

$$
\begin{aligned}
\hat{P}_{f}(t) & =F_{\boldsymbol{z}}(\mathbf{0})+\left\{1-F_{\boldsymbol{z}}(\mathbf{0})\right\} P_{f}^{\prime}(t) \\
& =1-\left\{1-F_{\boldsymbol{z}}(\mathbf{0})\right\} \exp \left[-\int_{0}^{t} P_{-}(\mathbf{0} \mid t) d t\right]
\end{aligned}
$$

さらに, 次式で与えられる $L(t)$ によ一て構造物の信 頼度を定義する.

$$
\begin{aligned}
L(t) & =1-\hat{P}_{f}(t) \\
& =\left\{1-F_{\mathbf{z}}(\mathbf{0})\right\} \exp \left[-\int_{0}^{t} p_{-}(\mathbf{0} \mid t) d t\right] \cdots
\end{aligned}
$$

この式からわかるように, 構造物の信頼度は, 時間の増 加とともに低下寸る.

構造物の耐用期間 $T$ における構造物の信頼度 $L(t)$ $=L(T)$ とその破壊確率 $Q$ とを関係ゔす式は,

$$
1-Q=\left\{1-F_{\boldsymbol{z}}(\mathbf{0})\right\} \exp \left[-\int_{0}^{T} p_{-}(\mathbf{0} \mid t) d t\right]
$$

のようになる。山烒より

$$
\int_{0}^{T} p_{-}(\mathbf{0} \mid t) d t=\ln \left\lfloor 1-F_{\boldsymbol{z}}(\mathbf{0})\right\rfloor-\ln \lfloor 1-Q\rfloor
$$

特に, 荷重および部材強度が定常確率過程の場合は,

$$
p_{-}(\mathbf{0})=\frac{\ln \left[1-F_{z}(\mathbf{0})\right]-\ln [1-Q]}{T}
$$

式（5）および（8）の積分を行って，構造物の破壊確 率 $Q\left(=\left.\hat{P}_{f}(t)\right|_{t=T}\right)$ を見出すのは, 部材数の 増加に伴 


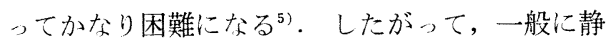
定構造系の破壊の確率は，個々の部材の破壊の事 象が統計的に独立，才なわち個々の部材の部材力 が互いに統計的に独立であり，各部材の強度も㱏 いに独立であるとして部算される．部材力が互い に独立であるといら仮定は明らかに正しくない が，計算が容易に行えるといら理由から，この仮 定のもとでQを算出する場合が多い，そ机をQ* とする.

もら一つの特別な場合として，個々の部材の破 壊の事象が完全相関関係にある場合を考える.こ の場合の構造系の破壊の確率を $Q^{* *}$ とすると,

$$
Q^{* *}=\max \left[Q_{1}, Q_{2}, \cdots, Q_{n}\right]
$$

ここに, $Q_{i}$ は部材 $i$ の破壊確率である.

$Q$ の特別な場合として $Q^{*}$ および $Q * *$ を考えたが， これらの間には,

$$
Q^{* *} \leq Q \leq Q^{*}
$$

なる不等式が成立する ${ }^{6}$. 構造系の 破壊の確率 $Q$ の推 定值には, 上限值 $Q^{*}$ および下限值 $Q^{* *}$ が近似解とし て用いられるが，これらの限界值が大きく異なっている 場合には粗雑な推定值となる。

\section{3. 正規定常確率過程の場合の破壞確率の算定}

2.で述べた理論け，任意の分布型を有する確率過程 に適用できるものであるが，本論文では，一般に広く用 いられる正規定常確率過程について述心゙る。

構造物に作用する荷重 $S_{j}(t)(j=1,2, \cdots, m)$ およよ゙ 部材強度 $\boldsymbol{R}(t)$ がいずれも正規定常確率過程であり，か つ互いに非相関である場合を考える．構造物の老朽化の 本質からして， $R(t)$ は非定常であるが，ここでは簡単 のために定常確率過程であると考える.そうすると, 静 定系の構造解析により求まる部材力 $\boldsymbol{X}(t)$ も正規定常 確率過程となるので, 強度の余裕 $\boldsymbol{Z}(t)$ も正規定常確率 過程である.したがって,この場合の結合確率密度 $f(\boldsymbol{z}, \dot{\boldsymbol{z}})$ は,

$$
f(\boldsymbol{z}, \dot{\boldsymbol{z}})=f_{\boldsymbol{z}}(\boldsymbol{z}) \cdot f_{\dot{\boldsymbol{z}}}(\dot{\boldsymbol{z}})
$$

という形をしている. 確率密度 $f_{z}(z)$ は,

$$
\begin{aligned}
f_{\boldsymbol{z}}(\boldsymbol{z})= & \frac{1}{(2 \pi)^{n / 2}|M|^{1 / 2}} \\
& \times \exp \left[-\frac{1}{2}\{\boldsymbol{z}-\overline{\boldsymbol{z}}\}^{T} \boldsymbol{M}^{-1}\{\boldsymbol{z}-\overline{\boldsymbol{z}}\}\right]
\end{aligned}
$$

で表わされる.ここに， $\{\boldsymbol{z}-\overline{\boldsymbol{z}}\}$ 㳉， $z_{i}-\bar{z}_{i}(i=1,2, \cdots$, $n$ ）を要素にもつ列マトリックスで，上添字 ${ }^{T}$ の記号そ の転置を意味する. $M$ は相関マトリックスであり, $|M|$ はその行列式である。また，次のような関係式が成り立
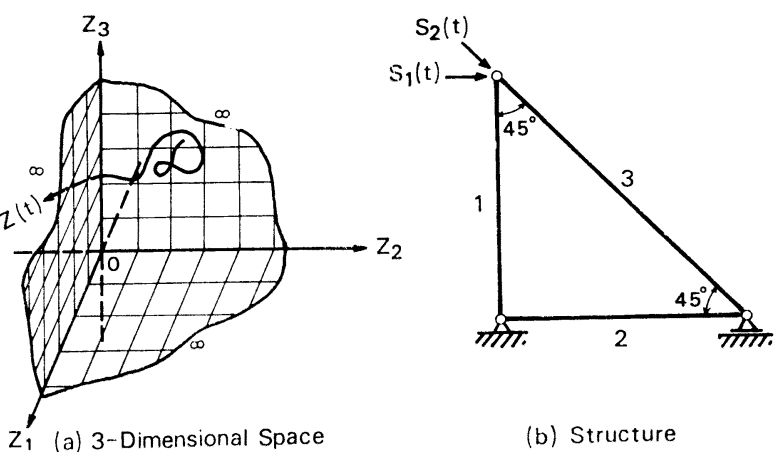

rig. 2 Three-Member Truss

ว.

$$
\boldsymbol{M}=\mathbf{E}\left[\{\boldsymbol{z}-\overline{\boldsymbol{z}}\}\{\boldsymbol{z}-\overline{\boldsymbol{z}}\}^{T}\right]
$$

ここに， $\mathbf{E}$ は期待值を求める演算記号である.

同様に, 確率密度 $f_{\dot{\boldsymbol{z}}}(\dot{\boldsymbol{z}})$ は，次のように表わされる。

$$
\begin{aligned}
& f_{\dot{\boldsymbol{z}}}(\dot{\boldsymbol{z}})=\frac{1}{(2 \pi)^{n / 2}|U|^{1 / 2}} \exp \left[-\frac{1}{2} \dot{\boldsymbol{z}}^{T} \boldsymbol{U}^{-1} \dot{\boldsymbol{z}}\right] \\
& \boldsymbol{U}=E\left[\dot{z} \dot{z}^{T}\right]
\end{aligned}
$$

上記の式 (16)〜（20）を式（5）および（8）に適用す ることにより, 式 (9) から $n$ 次元問題における破壊確 率の算定式を導くことができるが，ここでは， $n$ 次元の 場合の式を用いて，Fig. 2(b) で示されるような 3 部材 静定卜ラスに互いに統部的に独立な荷重 $S_{1}(t)$ および $S_{2}(t)$ が作用する場合について考える.このような 3 部 材での破壊の問題は, Fig. 2(a) で示される 3 次元空閒 でのランダムベクトル $\boldsymbol{Z}(t)$ の正領域から負領域への超 過の問題に置き換えられる.

したがって,この場合の超過確率の 時閒密度 $p_{-}(\mathbf{0})$ は, 式（5）から次のように表わされる.

$$
\begin{aligned}
p_{-}(\boldsymbol{0})= & -\left[\int_{0}^{\infty} \int_{0}^{\infty} f_{\boldsymbol{z}}\left(0, z_{2}, z_{3}\right) d z_{2} d z_{3}\right. \\
& \times \int_{-\infty}^{\infty} \int_{-\infty}^{\infty} d \dot{z}_{2} d \dot{z}_{3} \int_{-\infty}^{0} f_{\dot{\boldsymbol{z}}}\left(\dot{z}_{1}, \dot{z}_{2}, \dot{z}_{3}\right) \dot{z}_{1} d \dot{z}_{1} \\
& +\int_{0}^{\infty} \int_{0}^{\infty} f_{\boldsymbol{z}}^{\boldsymbol{z}}\left(z_{1}, 0, z_{3}\right) d z_{1} d z_{3} \\
& \times \int_{-\infty}^{\infty} \int_{-\infty}^{\infty} d \dot{z}_{1} d \dot{z}_{3} \int_{-\infty}^{0} f_{\dot{\boldsymbol{z}}}\left(\dot{z}_{1}, \dot{z}_{2}, \dot{z}_{3}\right) \dot{z}_{2} d \dot{z}_{2} \\
& +\int_{0}^{\infty} \int_{0}^{\infty} f_{\boldsymbol{z}}\left(z_{1}, z_{2}, 0\right) d z_{1} d z_{2} \\
& \left.\times \int_{-\infty}^{\infty} \int_{-\infty}^{\infty} \int d \dot{z}_{1} d \dot{z}_{2} \int_{-\infty}^{0} f_{\dot{\boldsymbol{z}}}\left(\dot{z}_{1}, \dot{z}_{2}, \dot{z}_{3}\right) \dot{z}_{3} d \dot{z}_{3}\right]
\end{aligned}
$$

そして式 (18) で与えられる相関マトリックスとその行 列式および式 (20) で与えられる相関マトリックスは,

$$
\boldsymbol{M}=\left[\begin{array}{ccc}
\sigma_{z_{1}}{ }^{2} & K_{z_{1} z_{2}} & K_{z_{1} z_{3}} \\
K_{z_{2} z_{1}} & \sigma_{z_{2}}{ }^{2} & K_{z_{2} z_{3}} \\
K_{z_{3} z_{1}} & K_{z_{3} z_{2}} & \sigma_{z_{3}}{ }^{2}
\end{array}\right],
$$




$$
\begin{aligned}
& |M|=\sigma_{z_{1}} \sigma_{z_{2}} \sigma_{z_{3}}\left[\begin{array}{ccc}
1 & \rho_{12} & \rho_{13} \\
\rho_{21} & 1 & \rho_{23} \\
\rho_{31} & \rho_{32} & 1
\end{array}\right], \\
& \boldsymbol{U}=\left[\begin{array}{ccc}
\sigma_{\dot{z}_{1}}{ }^{2} & K_{\dot{z}_{1} \dot{z}_{2}} & K_{\dot{z}_{1} \dot{z}_{3}} \\
K_{\dot{z}_{2} \dot{z}_{1}} & \sigma_{\dot{z}_{2}}{ }^{2} & K_{\dot{z}_{2} \dot{z}_{3}} \\
K_{\dot{z}_{3} \dot{z}_{1}} & K_{\dot{z}_{3} \dot{z}_{2}} & \sigma_{\dot{z}_{3}}{ }^{2}
\end{array}\right]
\end{aligned}
$$

となる。ここに， $\sigma_{z_{i}}{ }^{2}$ および $\sigma_{\dot{z}_{i}}{ }^{2}$ は，それぞれ $Z_{i}(t)$ および $\dot{Z}_{i}(t)$ の分散で, $K_{z_{i} z_{j}}$ および $\rho_{i j}$ は，それぞれ 同一時刻 $t$ における $Z_{i}(t)$ と $Z_{j}(t)$ の相関モーメント および相関係数である.ただし相関マトリックスの対称 性より $\rho_{i j}=\rho_{j i}$ である. また， $K_{\dot{z}_{i} \dot{z}_{j}}$ は同一時刻 $t$ に おける $\dot{Z}_{i}(t)$ と $\dot{Z}_{j}(t)$ の相関モーメントである.

$\sigma_{z_{i}}{ }^{2}, \sigma_{\dot{z}_{i}}{ }^{2}$ および $\rho_{i j}$ は, $R_{i}(t), R_{j}(t), X_{i}(t)$ および $X_{j}(t)$ の各特性值を用いて次のように表わされる.

$$
\begin{aligned}
& \sigma_{z_{i}}{ }^{2}=\sigma_{r_{i}}{ }^{2}+\sigma_{x_{i}}{ }^{2}, \\
& \sigma_{\dot{z}_{i}}{ }^{2}=\sigma_{\dot{r}_{i}}{ }^{2}+\sigma_{\dot{x}_{i}}{ }^{2}=-K_{r_{i}}{ }^{\prime \prime}(0)-K_{x_{i}}{ }^{\prime \prime}(0), \\
& \rho_{i j}=\frac{K_{z_{i} z_{j}}}{\sigma_{z_{i}} \sigma_{z_{j}}}=\frac{\rho_{r_{i} r_{j}} \sigma_{r_{i}} \sigma_{r_{j}}+\rho_{x_{i} x_{j}} \sigma_{x_{i}} \sigma_{x_{j}}}{\sqrt{\sigma_{r_{i}}{ }^{2}+\sigma_{x_{i}}{ }^{2}} \sqrt{\sigma_{r_{i}}{ }^{2}+\sigma_{x_{i}}{ }^{2}}} ; \\
& (i=1,2,3)
\end{aligned}
$$

ここに， $K_{r_{i}}(\tau)$ および $K_{x_{i}}(\tau)$ は，それぞれ $R_{i}(t)$ お よび $X_{i}(t)$ の相関関数で, "の記号は $\tau$ の 2 階微分を 表わす. また, $\rho_{r_{i} r_{j}}$ および $\rho_{x_{i} x_{j}}$ は, それぞれ部材 $i$ と 部材 $j$ の強度および部材力の相関係数で, $\rho_{r_{i} r_{j}}=\rho_{r_{j} r_{i}}$ および $\rho_{x_{i} x_{j}}=\rho_{x_{j} x_{i}}$ である.

この場合の超過確率の 時間密度 $p_{-}(\mathbf{0})$ および載荷の 最初の時点で破壊寸る確率 $F_{\boldsymbol{z}}(\mathbf{0})$ は, 式 (17) および (19) で $n=3$ として, それぞれ式 (21) および (8)に 代入すれば得られるが，その際に次のような記号を導入 する。

$$
\begin{aligned}
& V_{r_{i}}{ }^{2}=\left(\sigma_{r_{i}} / \bar{r}_{i}\right)^{2}, V_{x_{i}}{ }^{2}=\left(\sigma_{x_{i}} / \bar{x}_{i}\right)^{2}, \\
& B_{r_{i}}{ }^{2}=-K_{r_{i}}{ }^{\prime \prime}(0) /\left(\bar{r}_{i}\right)^{2}, B_{x_{i}}{ }^{2}=-K_{x_{i}}{ }^{\prime \prime}(0) /\left(\bar{x}_{i}\right)^{2}, \\
& \nu_{i}=\bar{r}_{i} / \bar{x}_{i}, \quad z_{i}{ }^{*}=z_{i} / \sigma_{z_{i}} ; \quad(i=1,2,3)
\end{aligned}
$$

ここに， $V_{r_{i}}$ および $V_{x_{i}}$ は，それぞれ部材 $i$ の強度お よび部材力の 変動係数, $\nu_{i}$ は, 部材 $i$ の中央安全率と 呼ばれるものである.

そうすると, $p_{-}(\mathbf{0})$ および $F_{\boldsymbol{z}}(\mathbf{0})$ は, 次式のように なる・

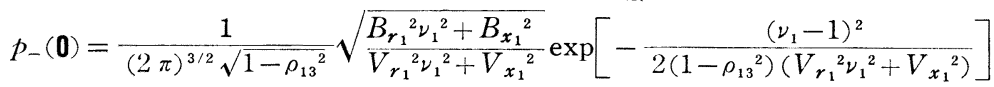

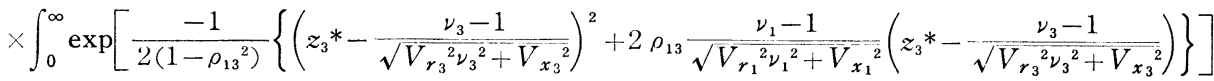

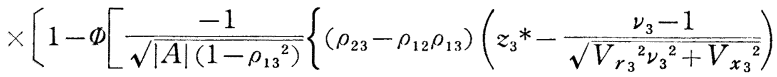

$$
\begin{aligned}
& \left.\left.-\left(\rho_{12}-\rho_{13} \rho_{23}\right) \frac{\nu_{1}-1}{\sqrt{V_{r_{1}}{ }^{2} \nu_{1}{ }^{2}+V_{x_{1}}{ }^{2}}}+\left(1-\rho_{13}{ }^{2}\right) \frac{\nu_{2}-1}{\sqrt{V_{r_{2}}{ }^{2} \nu_{2}{ }^{2}+V_{x_{2}}{ }^{2}}}\right\}\right] d z_{3}{ }^{*}
\end{aligned}
$$

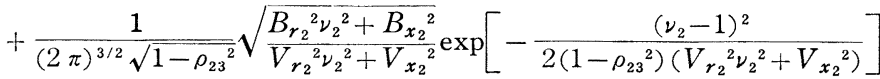

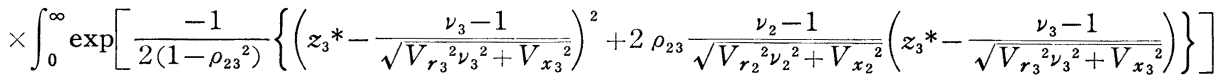

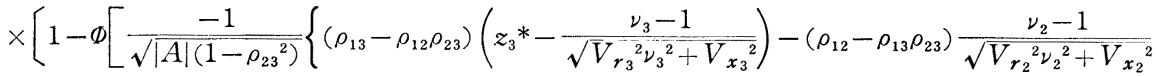

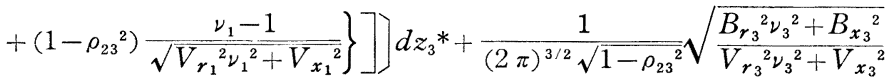

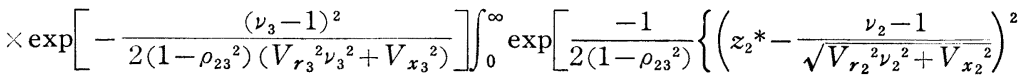

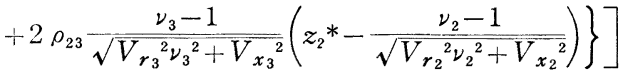

$$
\begin{aligned}
& \times\left[1-\Phi\left[\frac { - 1 } { \sqrt { | A | ( 1 - \rho _ { 2 3 } { } ^ { 2 } ) } } \left\{\left(\rho_{12}-\rho_{13} \rho_{23}\right)\left(z_{2} *-\frac{\nu_{2}-1}{\sqrt{V_{r_{2}}{ }^{2} \nu_{2}{ }^{2}+V_{x_{2}}{ }^{2}}}\right)\right.\right.\right.
\end{aligned}
$$

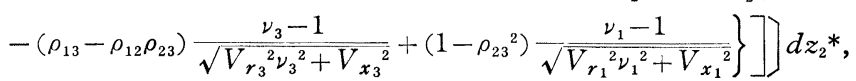



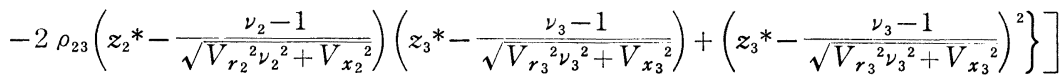

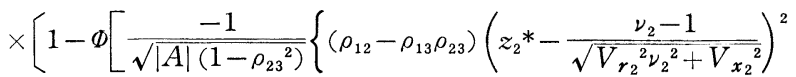

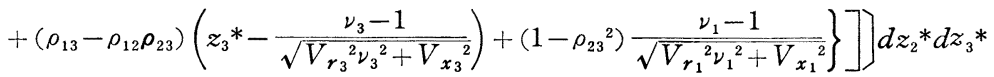


ここに, $\Phi(\gamma)$ は,

$$
\Phi(r)=\frac{1}{\sqrt{2 \pi}} \int_{-\infty}^{r} \exp \left(-\frac{1}{2} u^{2}\right) d u
$$

で与えられる正規確率積分で, $|A|$ は, 式 (22) におけ る相関係数マトリックスの行列式で, $|A|=1-\rho_{12}{ }^{2}-\rho_{13}{ }^{2}$ $-2 \rho_{12} \rho_{13} \rho_{23}$ である. そして相関係数 $\rho_{i j}$ は, 次式で表 わされる.

$$
\rho_{i j}=\frac{\rho_{r_{i} r_{j} \nu_{i} \nu_{j}} V_{r_{i}} V_{r_{j}}+\rho_{x_{i} x_{j}} V_{x_{i}} V_{x_{j}}}{\sqrt{V_{r_{i}}{ }^{2} \nu_{i}{ }^{2}+V_{x_{i}}{ }^{2}} \sqrt{V_{r_{j}{ }^{2} \nu_{j}{ }^{2}+V_{x_{j}}{ }^{2}}}}
$$

したがって，Fig. 2(b) に示す 3 部材トラスに関する破 壊確率の算定式は, 式 (25) および (26) を式 (13) に代 入することによって得られる.

ところで, Fig. 2(b) に示される静定トラスの各部材 力は, 簡単な構造解析より求まり次のようになる.

$$
\begin{aligned}
& X_{1}=S_{1} \\
& \text { (引張り) } \\
& X_{2}=S_{1}+(1 / \sqrt{2}) S_{2} \\
& \text { (引張り) } \\
& X_{3}=\sqrt{2} S_{1}+S_{2}
\end{aligned}
$$

荷重 $S_{1}(t)$ および $S_{2}(t)$ は, 正規定常確率過程で互い に統計的に独立であるから， $V_{x_{i}}{ }^{2}, B_{x_{i}}{ }^{2}$ および $\nu_{i}(i=1$,

2,3) は，それぞれ次のようになる。

$$
\begin{aligned}
& V_{x_{1}}{ }^{2}=V_{s_{1}}{ }^{2}, V_{x_{2}}{ }^{2}=\frac{2 V_{s_{1}}{ }^{2}+\beta_{21}{ }^{2} V_{s_{2}}{ }^{2}}{\left(\sqrt{ } 2+\beta_{21}\right)^{2}}, \\
& V_{x_{3}}{ }^{2}=\frac{2 V_{s_{1}}{ }^{2}+\beta_{21}{ }^{2} V_{s_{2}}{ }^{2}}{\left(\sqrt{2}+\beta_{21}\right)^{2}} \text {, } \\
& Q=1-\frac{1}{2 \pi \sqrt{1-\rho^{2}}} \int_{0}^{\infty} \int_{0}^{\infty} \exp \left[\frac{-1}{2\left(1-\rho^{2}\right)}\left\{\left(z_{2}^{*}-\bar{z}^{*}\right)^{2}-2 \rho\left(z_{2}^{*}-\bar{z}^{*}\right)\left(z_{3}^{*}-\bar{z}^{*}\right)+\left(z_{3}^{*}-\bar{z}^{*}\right)^{2}\right\}\right] \\
& \times\left[1-\Phi\left[\frac{-1}{\sqrt{\left(1-\rho^{2}\right)\left(1-3 \rho^{2}-2 \rho^{3}\right)}}\left\{\rho(1-\rho)\left(z_{2}{ }^{*}+z_{3}{ }^{*}-2 \bar{z}^{*}\right)+(1-\rho) \bar{z}^{*}\right\}\right]\right] d z_{2} * d z_{3} * \\
& \times \exp \left[\frac { - 3 T } { \sqrt { ( 2 \pi ) ^ { 3 } ( 1 - \rho ^ { 2 } ) } } \sqrt { \frac { B _ { r } { } ^ { 2 } \nu ^ { 2 } + B _ { s _ { 1 } } { } ^ { 2 } } { V _ { r } { } ^ { 2 } \nu ^ { 2 } + V _ { s _ { 1 } } { } ^ { 2 } } } \operatorname { e x p } [ - \frac { \overline { z } ^ { * 2 } } { 2 ( 1 - \rho ^ { 2 } ) } ] \int _ { 0 } ^ { \infty } \operatorname { e x p } \left[\frac { - 1 } { 2 ( 1 - \rho ^ { 2 } ) } \left\{\left(z^{*}-\bar{z}^{*}\right)^{2}\right.\right.\right. \\
& \left.\left.\left.+2 \rho \bar{z}^{*}\left(z^{*}-\bar{z}^{*}\right)\right\}\right]\left[1-\Phi\left(\frac{-1}{\sqrt{\left(1-\rho^{2}\right)\left(1-3 \rho^{2}-2 \rho^{3}\right)}}\left\{\rho(1-\rho)\left(z^{*}-\bar{z}^{*}\right)+(1-\rho) \bar{z}^{*}\right\}\right)\right] d z^{*}\right]
\end{aligned}
$$

$こ こ に$

$$
\left.\begin{array}{l}
\bar{z}^{*}=\frac{\nu-1}{\sqrt{V_{r}^{2} \nu^{2}+V_{s_{1}}{ }^{2}}}, \\
\rho=\rho_{12}=\rho_{13}=\rho_{23}=\frac{\rho_{r} \nu^{2} V_{r}{ }^{2}+\rho_{x} V_{s_{1}}{ }^{2}}{V_{r}{ }^{2} \nu^{2}+V_{s_{1}}{ }^{2}} .
\end{array}\right\}
$$

式 (31) において $\rho=0\left(\rho_{r}=\rho_{x}=0\right)$, すなわち個々の 部材の破壊の事象が統計的に独立な場合の破壊確率 $Q$ $=Q^{*}$ は, 次のように簡単になる.

$$
\begin{aligned}
& Q^{*}=1-\left[1-\Phi\left(\frac{1-\nu}{\sqrt{V_{r}^{2} \nu^{2}+V_{s_{1}}^{2}}}\right)\right]^{3} \\
& \quad \times \exp \left\{\frac{-3 T}{2 \pi} \sqrt{\frac{B_{r}{ }^{2} \nu^{2}+B_{s_{1}}{ }^{2}}{V_{r}{ }^{2} \nu^{2}+V_{s_{1}}{ }^{2}}}\right. \\
& \left.\quad \times \exp \left[\frac{-(\nu-1)^{2}}{2\left(V_{\left.r^{2} \nu^{2}+V_{s_{1}}{ }^{2}\right)}\right.}\right]\left[1-\Phi\left(\frac{1-\nu}{\sqrt{V_{r}{ }^{2} \nu^{2}+V_{s_{1}}{ }^{2}}}\right)\right]^{2}\right\}
\end{aligned}
$$

この式は, 式 (16)〜 (20) を考慮して $n$ 部材静定トラス に容易に拡張できる.すなわち

$$
\begin{aligned}
& Q^{*}=1-\left[1-\Phi\left(\frac{1-\nu}{\sqrt{V_{r^{2} \nu^{2}+V_{s_{1}}^{2}}^{2}}}\right)\right]^{N} \\
& \times \exp \left\{\frac{-N T}{2 \pi} \sqrt{\frac{B_{r}{ }^{2} \nu^{2}+B_{s_{1}}{ }^{2}}{V_{r}{ }^{2} \nu^{2}+V_{s_{1}}{ }^{2}}} \exp \left[\frac{-(\nu-1)^{2}}{2\left(V_{r}{ }^{2} \nu^{2}+V_{s_{1}}{ }^{2}\right)}\right]\right. \\
& \left.\times\left[1-\Phi\left(\frac{1-\nu}{\sqrt{V_{r}^{2} \nu^{2}+V_{s_{1}}^{2}}}\right)\right]^{N-1}\right\}
\end{aligned}
$$

ここに， $N$ は部材数である. この式において $N=1$ と すると, A.P. Ржаницын の式 ${ }^{1), 7}$ に一致する. そし てその時の $Q^{*}$ の值がこの場合の $Q^{* *}$ の值になる.

\section{4. 数値計算例および考察}

\section{（1）単一荷重が作用する場合}

3. で導いた式（31)〜(34) を用いて，Fig. 2(b) に 示した 3 部材静定トラスで, 単一荷重 $S_{1}(t)$ が作用す 
る場合の破壊確率 $Q, Q^{*}$ および $Q * *$ の計算を行う. 例として, すべての部材の部材強度が同一の変動係数 $V_{r}$ を有する正規確率変数であり, 荷重 $S_{1}(t)$ は, 相関 関数 $K_{s_{1}}(\tau)=\sigma_{s_{1}}{ }^{2} \exp \left(-\alpha_{1} \tau^{2}\right)$ を有する 正規定常確率 過程である場合を考える.この場合, 部材強度を確率変 数としているので, 部材強度の導関数に関するパラメー ター $B_{r}$ は， $B_{r}=0$ となる. さらに荷重 $S_{1}(t)$ の相関 関数が $K_{s_{1}}(\tau)=\sigma_{s_{1}}{ }^{2} \exp \left(-\alpha_{1} \tau^{2}\right)$ と与えられているか ら， $B_{s_{1}}{ }^{2}=2 \alpha_{1} V_{s_{1}}{ }^{2}$ になる.この計算に打いては， $\alpha_{1}=$ 1/day ${ }^{2}$ であるとした. また, 各部材の部材力は, 静定系 の構造解析より求まるから, これらの部材力は, 互いに 完全相関関係にあるので $\rho_{x}=1.0$ とし, 各部材強度の 相関係数は， $\rho_{r}=0,0.1$ のつの場合を考えた. そして 耐用期間 $T$ は, $T=0$ と $T=1000$ (days) とした.

各部材の破壊の事象の間の相関性を表わす相関係数 $\rho$ および部材強度の変動係数 $V_{r}$ が, どのように構造物の 全破壊確率 $Q$ に影響を抢よぼすかを調べるために，中 央安全率 $\nu$ と破壊確率 $Q$ との間の関係を Fig. 3 抢上 び Fig. 4 に示した. Fig. 3 は, $V_{s_{1}}=0.2, V_{r}=0.13$ の場合で, Fig. 4 は, $V_{s_{1}}=0.2, V_{r}=0.17$ の場合で

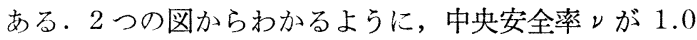
から 2.0 の小さな值では，破壊確率 $Q$ は， $\rho$ の影響を

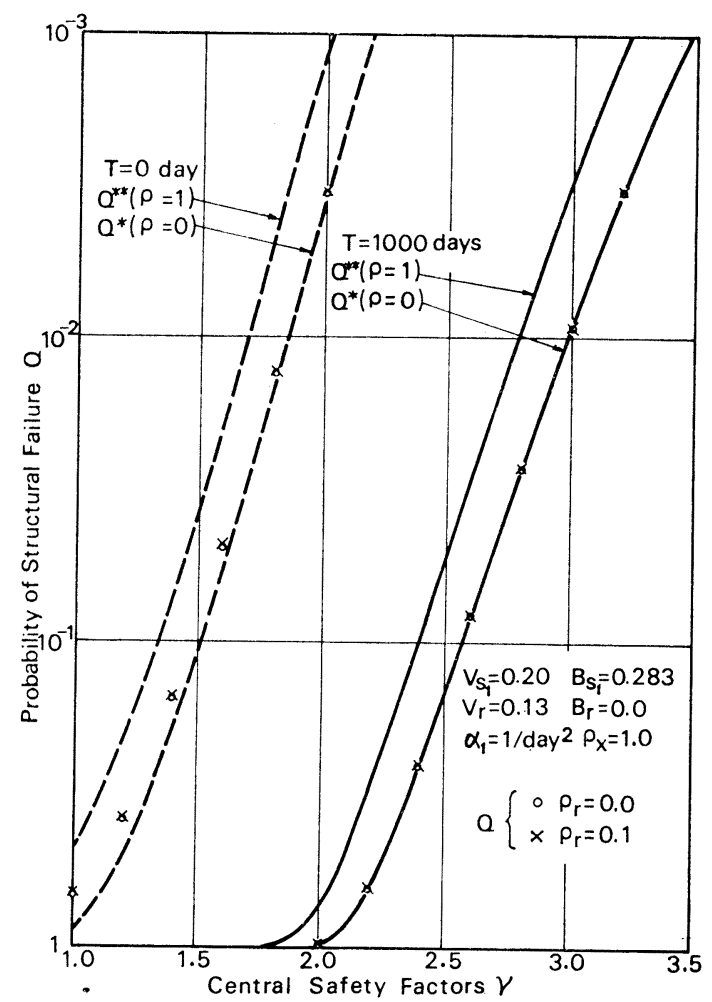

Fig. 3 Influence of Coefficient of Correlation for the Member Failures on Probability of Structural Failure $\left(V_{r}=0.13\right)$

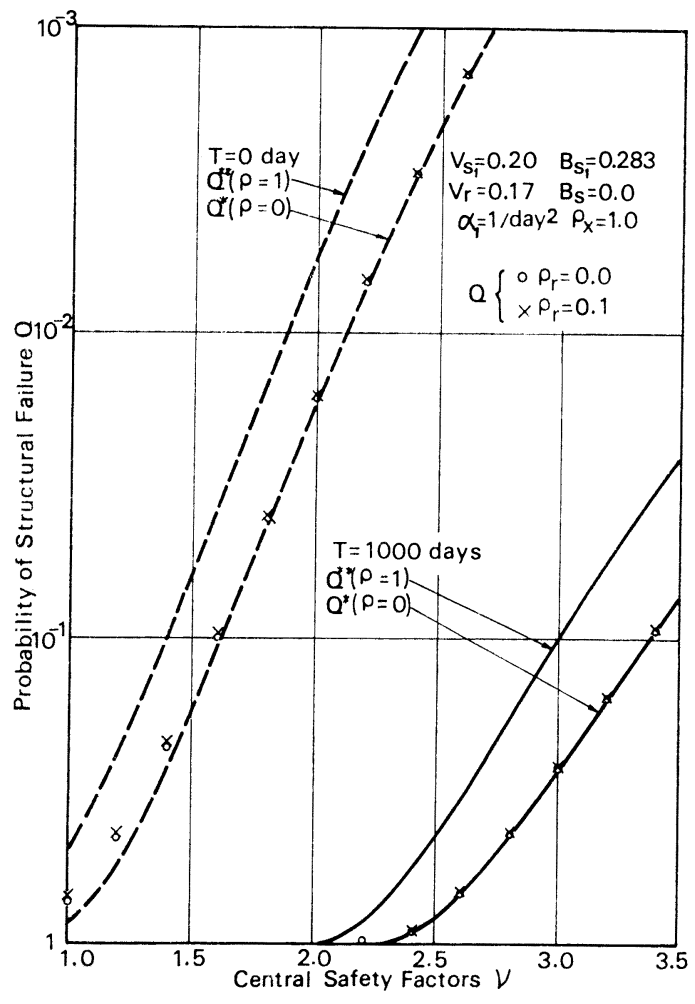

Fig. 4 Influence of Coefficient of Correlation for the Member Failures on Probability of Structural Failure $\left(V_{r}=0.17\right)$

Table 1 Value of Probability of Structural Failure $Q$

\begin{tabular}{|c|c|c|c|c|c|c|c|}
\hline \multirow{2}{*}{\multicolumn{2}{|c|}{$V_{r}\left|\widehat{\rho_{r}}\right|^{\nu}$}} & \multicolumn{3}{|c|}{$T=0($ day $)$} & \multicolumn{3}{|c|}{$T=1000$ (days) } \\
\hline & & 1.2 & 1.6 & 2.0 & 2.0 & 2.2 & 2.4 \\
\hline \multirow{3}{*}{0.13} & 0 & $\begin{array}{l}0.5166^{*} \\
0.3829\end{array}$ & $\begin{array}{l}0.0553^{*} \\
0.0458\end{array}$ & $\begin{array}{l}0.0034^{*} \\
0.0033\end{array}$ & $\begin{array}{l}0.981^{*} \\
0.978\end{array}$ & $\begin{array}{l}0.649^{*} \\
0.644\end{array}$ & $\begin{array}{l}0.252^{*} \\
0.251\end{array}$ \\
\hline & & 0.3733 & 0.0472 & 0.0033 & 0.976 & 0.641 & 0.250 \\
\hline & & $0.2152^{* *}$ & $0.0188^{* *}$ & $0.0011^{* *}$ & $0.732^{* *}$ & $0.295^{* *}$ & $0.092^{* *}$ \\
\hline \multirow{4}{*}{0.17} & 0 & $0.5644^{*}$ & $0.1091^{*}$ & $0.0168^{*}$ & $1.000^{*}$ & $0.997^{*}$ & $0.924^{*}$ \\
\hline & & 0.4535 & 0.0986 & 0.0164 & 1.000 & 0.997 & 0.922 \\
\hline & 01 & 0.4410 & 0.0958 & 0.0161 & 1.000 & 0.996 & 0.921 \\
\hline & & $0.2419^{* *}$ & $0.0378^{* *}$ & $0.0056^{* *}$ & $0.990^{* *}$ & $0.856^{* *}$ & $0.577^{* *}$ \\
\hline
\end{tabular}

$V_{s_{1}}=0.2, B_{s_{1}}=0.283, B_{r}=0.0, \alpha_{1}=1 / \mathrm{day}^{2}, \rho_{x}=1.0$

たたしし，*および**の值は，それぞれ $Q^{*}\left(\rho_{\boldsymbol{x}}=\rho_{\boldsymbol{r}}=0\right)$ および $Q^{* *}\left(\rho_{\boldsymbol{x}}\right.$ $=\rho_{r}=1$ )の值である.

Table 2 Value of Coefficient of Correlation $\rho$

\begin{tabular}{|c|c|c|c|c|}
\hline & \multicolumn{2}{|c|}{$V_{r}=0.13$} & \multicolumn{2}{|c|}{$V_{r}=0.17$} \\
\hline$\nu \quad e_{r}$ & 0 & 0.1 & 0 & 0.1 \\
\hline 1.0 & 0.703 & 0.733 & 0.581 & 0.622 \\
\hline 1.2 & 0.622 & 0.660 & 0.490 & 0.541 \\
\hline 1.6 & 0.480 & 0.532 & 0.351 & 0.416 \\
\hline 2.0 & 0.372 & 0.435 & 0.257 & 0.331 \\
\hline 2.2 & 0.328 & 0.396 & 0.222 & 0.300 \\
\hline 2.4 & 0.291 & 0.362 & 0.194 & 0.274 \\
\hline
\end{tabular}

$V_{s_{1}}=0.2, B_{s_{1}}=0.283, B_{r}=0.0, \alpha_{1}=1 / \mathrm{day}^{2}, \rho_{x}=1.0$ 
けて $Q^{*}(\rho=0)$ と $Q^{* *}(\rho=1)$ の間にあり, 式 (15) の 関係を満たしていることがわかる.レが 2.0 以上にな るとその影響もなくなりほとんど $Q^{*}$ の曲線と一致す る.したがって, $T=1000$ (days) の場合の $Q$ の值は, ほとんど $Q^{*}$ の值に一致する. この傾向は， $V_{r}$ の值が 大きいほど顕著である.具体的な数值は, Table 1 に示 す.このような傾向は, 従来の解析結果 ${ }^{8)}$ においても見 られるが，これは式 (32) で示される $\rho$ の值が Table 2 に示すように, レと $V_{r}$ の増大にともなって小さくな るからである. また，Fig. 3 および Fig. 4 からわか るように, 破壊確率の值は, $T=0$ の場合より $T=1000$ (days) の方がかなり大きい.そして $T$ の值にかかわら ず $V_{r}$ の值が大きいほど破壊確率は大きくなるが, その 傾向は $T=0$ より $T=1000$ (days) の場合の方がより 顕著である.

以上は, 部材数 $n=3$ の場合の結果であるが, このよ うな傾向は $n$ が増加しても必らず認められるものと考え られる. したがって, 本論文で考えているような静定卜 ラスの確率過程論による信頼性解析においては, 各部材 間の破壊事象の間の相関性を考慮しなくてもある程度の 精度で破壊確率の算定が可能である. そこで, これ以後 の数值計算は, 各部材間の破壊事象が統計的に独立な場 合で, $n$ 部材静定トラスに適用できる式 (34) を用いて 行うことにし，その他の条件は，この節のはじめに示し たものを用いることにする。

まず Fig. 5 は, 風あるいは地震のように荷重の変動
にするために必要な $N=1$ の場合の中央安全率 $\nu(1)$ に 対する任意の部材数 $N$ の場合の 中央安全率 $\nu(N)$ の 比, すなわち相対安全率と部材数 $N$ との間の関係を $T$ $=0$ と $T=1000$ (days) の場合について Fig. 7 に示 す.この図から明らかなように, 強度の変動性が優位を

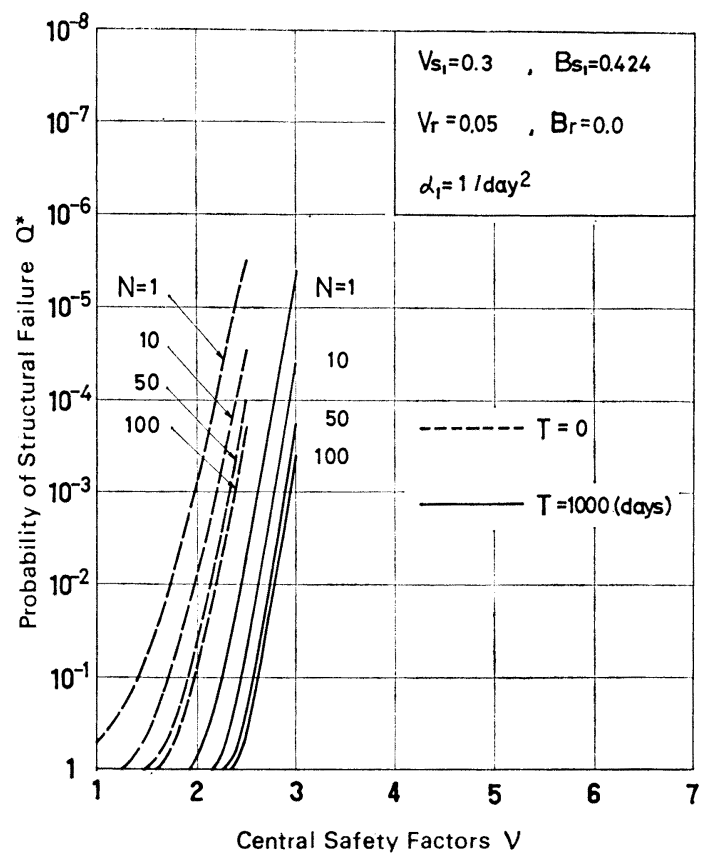

Fig. 5 Probability of Structural Failure for the Case of Load Variability Dominance
係数が強度の変動係数を大きく上まわってい るような場合の構造物の破壊 確率 $Q^{*}$ が部 材数 $N$ および耐用期間 $T$ とどのような関 係にあるかを調べるために, $V_{s_{1}}=0.3, V_{r}=$ $0.05, T=0,1000$ (days), $N=1,10,50,100$ の場合の中央安全率 $\nu$ と破壊確率 $Q^{*}$ の間 の関係を示したものである.Fig. 6 は, 死 荷重載荷の場合のように強度の変動性が優位 を占めるような場合の構造物の破壊確率 $Q^{*}$ が $N$ および $T$ とどのような関係にあるか を調べるために， $V_{s_{1}}=0.2, V_{r}=0.15$ とし て Fig. 5 と同様なグラフを示す. 2 つの図 からわかるように， $V_{s_{1}}$ が $V_{r}$ よりも優位を 占める場合は, $Q^{*}=0.5 \times 10^{-3}$ の值を得るた めには, 中央安全率 $\nu$ は, $T=0$ で $N=1$ の とき $\nu=2.05, N=10$ のとき $\nu=2.25$ であ ればよいが, $V_{r}$ が $V_{s_{1}}$ よりも優位を占め る場合は， $N=1$ のとき $\nu=2.2, N=10$ の とき $\nu=2.8$ が必要となる. この傾向は, $T$ と $N$ の増加にともなって顕著になる.この 傾向を詳細に 調べるために, $Q^{*}=0.5 \times 10^{-3}$

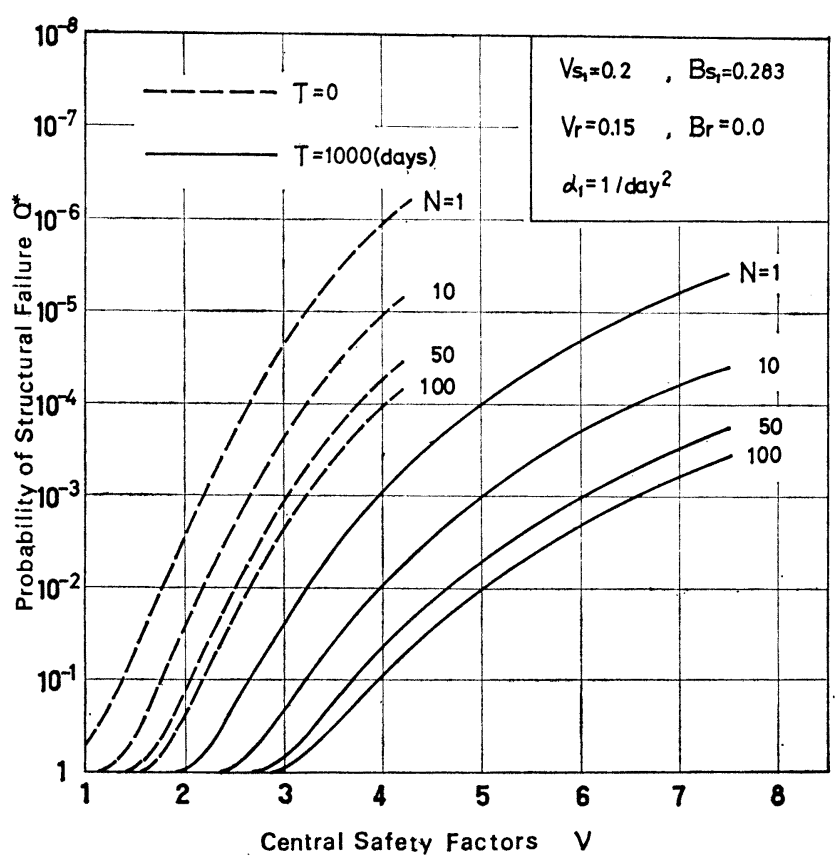

Fig. 6 Probability of Structural Failure for the Case of Strength Variability Dominance 


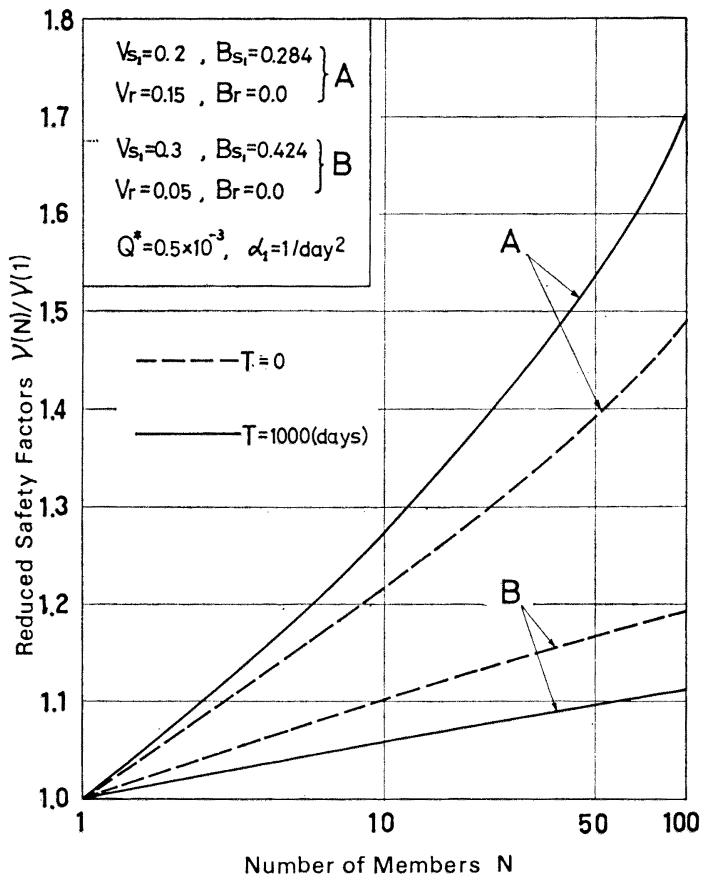

Fig. 7 Reduced Safety Factor versus Number of Elements

占める場合は, 部材数 $N$ の増加に伴って中央安全率 $\nu$ をかなり増加させなければならない.すなわち相対安全 率を 1.0 以上にとらなければならない. 荷重の変動性 が優位を占める場合は，Nが増加しても部材数が 1 の

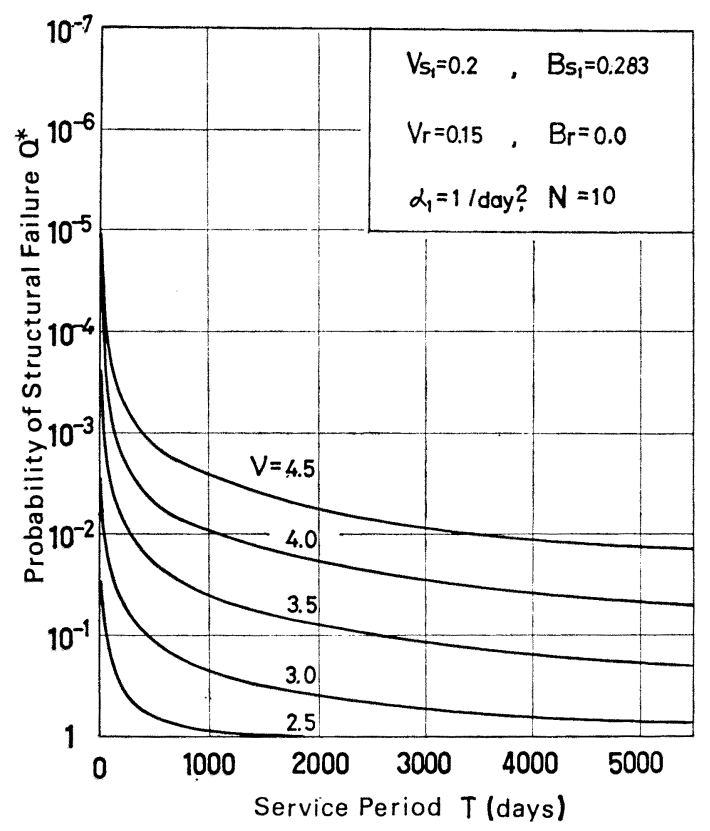

Fig. 8 Relationship between the Probability of Structural Failure and Service Period

部材強度の変動係数 $V_{r}$ の破壊確率 $Q^{*}$ におよぼす影 響については, 単一部材の場合にはすでに研究され2),3), $Q^{*}$ は $V_{r}$ に非常に敏感であることがわかっているが, ここでは多部材要素からなる構造物についてもその影響 がどのようになるかを調べるために， $V_{s_{1}}=0.2, T=$ 1000 (days), $N=1,10$ で $V_{r}=0.0,0.1,0.15$ と変化
場合の中央安全率に近い值でよい。すなわち 相対安全率が 1.0 に近い值でよい. またこ れらの傾向は, $T=0$ の場合よりも $T=1000$ (days) の場合の方がより顕著である.以上 の結果から，本論文で述べたような耐用期間 $T$ を考慮した確率過程論に基づく構造物の 信頼性解析の重要性が強調される.

構造物の耐用期間 $T$ の破壊確率 $Q^{*}$ にお よぼす影響の大きさを示すために， $\nu=2.5 \sim$ 4.5 と変化させた場合の $Q^{*}$ と $T$ との間の 関係を Fig. 8 に示す. ただし， $V_{s_{1}}=0.2$, $V_{r}=0.15, N=10$ の場合を考えることにす る.図からわかるように, $Q^{*}$ は $\nu=3.5$ の值 では $T=0$ から $T=1000$ (days)の間で $10^{-3}$ から $10^{-1}$ のオーダに急激に増加し, それ以 後もなめらかに増加している. $Q^{*}$ の值は, $T$ の増加に伴ってかなり大きくなることが わかる.したがって, 前述したように構造物 を安全に設計するためには, 確率過程論に基 ゔいた信頼性解析が必要であることはこの 図からも明らかである。

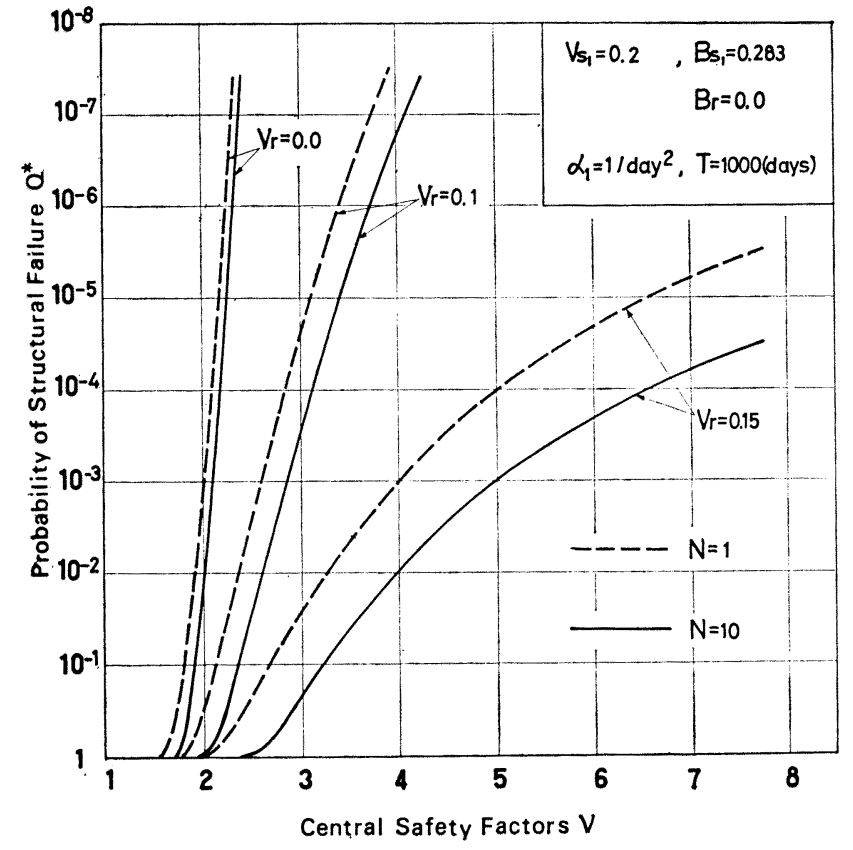

Fig. 9 Influence of Coefficient of Variation of Strength on Probability of Structural Failure 
させた場合の $Q^{*} と \nu の$ 間の関係を Fig. 9 に示す.ここに $V_{r}=0.0$ の場合とは, 強度 が確定值である場合で，その特性值として $\bar{r}$ を用いた場合である.すなわち本来確率量で あるべき強度を確定値として，その平均値を 用いた場合である. 図から明らかなように，

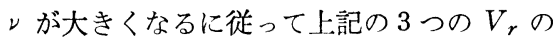
值に対応寸る曲線群は互いに大きく離れてく る.これは $\nu$ の増加に伴って破壊確率 $Q^{*}$ の算定誤差が著しく増加することを意味して いる.この傾向は, 部材数が大きい場合の方 が著しい.また $V_{r}$ が 0.1 から 0.15 とわ ずか 0.05 增加しただけで, $N=10, \nu=3.5$ の場合において $Q^{*}$ は $10^{-5}$ のオーダから $10^{-1}$ のオーダに増加している. すなわち $Q^{*}$ は， $V_{r}$ に非常に敏感であることがわかる. この傾向をさらに詳しく調べるために， $V_{s_{1}}$ $=0.2, T=1000$ (days), $N=10$ の場合で $\nu=2.5 \sim 4.0$ と変化させた場合の $Q^{*}$ と $V_{r}$ の間の関係を Fig. 10 に示す. この図から

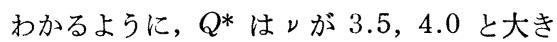

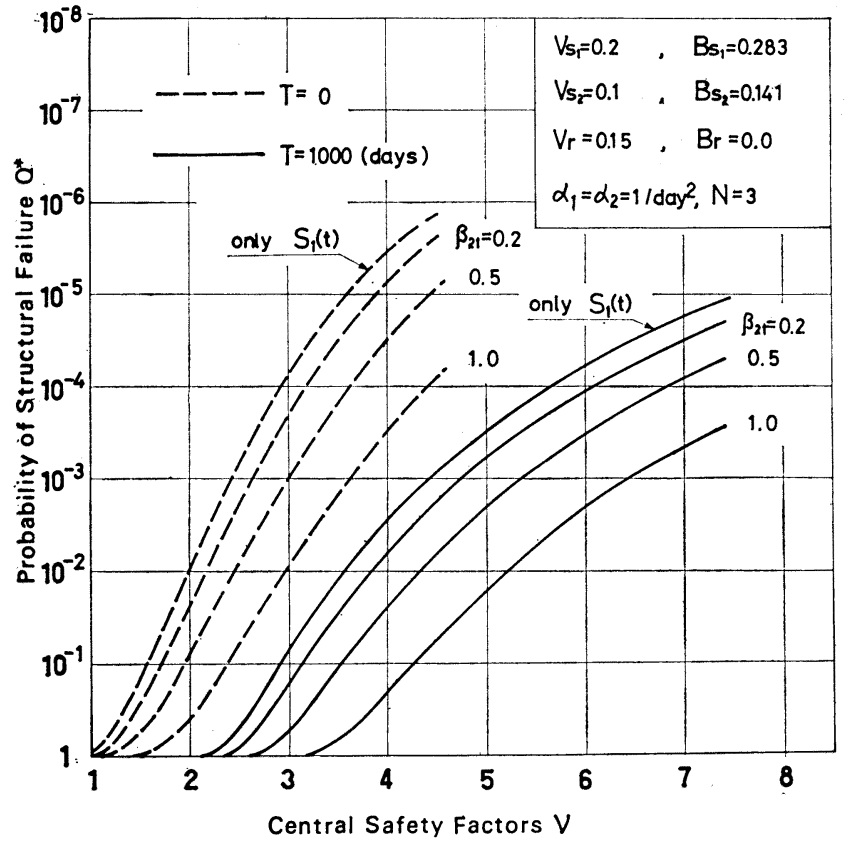

Fig. 11 Probability of Structural Failure subject to Two Loads

\section{（2）２つの荷重が作用する場合}

Fig. 2 に示されているような 3 部材静定トラスに荷 重 $S_{1}(t)$ および $S_{2}(t)$ が作用する場合で, 各部材の破 壊事象が 統計的に独立な場合の破壊確率 $Q^{*}$ の計算を行 ら. 例として, 強度が 3 部材とも同一の変動係数 $V_{r}$ を 有する正規確率変数であり, 荷重 $S_{1}(t)$ および $S_{2}(t)$ は，それぞれ相関関数 $K_{s_{1}}(\tau)=\sigma_{s_{1}}{ }^{2} \exp \left(-\alpha_{1} \tau^{2}\right)$ およ び $K_{s_{2}}(\tau)=\sigma_{s_{2}}{ }^{2} \exp \left(-\alpha_{2} \tau^{2}\right)$ を有する互いに 統計的に 独立な正規定常確率過程である場合を考える.この場合 も前節と同様, 強度の導関数佂関する パラメーター $B_{r}$ は， $B_{r}=0$ となる.さらに荷重 $S_{1}(t)$ および $S_{2}(t)$ の導 関数に関するパラメーターは,それぞれ $B_{s_{1}}{ }^{2}=2 \alpha_{1} V_{s_{1}}{ }^{2}$ および $B_{s_{2}}{ }^{2}=2 \alpha_{2} V_{s_{2}}{ }^{2}$ となる. 前節と同様に, この場 合も常に $\alpha_{1}=\alpha_{2}=1 /$ day $^{2}$ としておく.また, 部材 強度は荷重の数が増加し ても変化しないものとす ると, この場合の各部材 の中央安全率と $S_{1}(t) の$ みが作用した前節の場合 の部材の中央安全率 $\nu$ と の間の関係は, $\nu_{1}=\nu, \nu_{2}$ $=\nu_{3}=\sqrt{2} \nu /\left(\sqrt{2}+\beta_{21}\right)$ となる $\left(\beta_{21}=\bar{s}_{2} / \bar{s}_{1}\right)$.

以上より, 式 (25) お

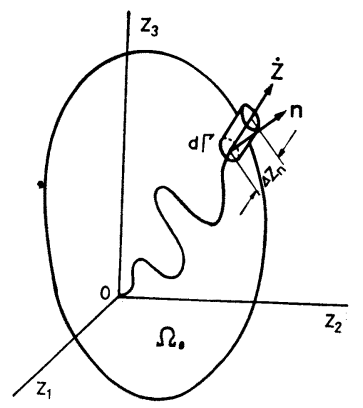

Fig. 12 Threshold Crossing in Multidimensional Space 
よび（26）に扔いて $\rho=0$ として式（13）に代入して求 められる破壊確率 $Q^{*}$ と前節の場合で $N=3$ として求 められる破壊確率 $Q^{*}$ を $S_{1}(t)$ のみが作用したときの 部材の 中央安全率 $\nu$ を横軸にとって示したのが Fig. 11 である.ただし, $V_{r}=0.15, V_{s_{1}}=0.2, V_{s_{2}}=0.1$, $\beta_{21}=0.2,0.5,1.0, T=0,1000$ (days) とした. 図から わかるように, $\beta_{21}$ が $0.2,0.5,1.0$ と増加するごとに， すなわち $S_{2}(t)$ の荷重の平均値が増大するごとに, 荷 重 $S_{1}(t)$ および $S_{2}(t)$ がともに作用した場合の破壊確 率は, 当然荷重 $S_{1}(t)$ のみが作用した場合の破壊確率 よりもかなり大きくなっている. また, この傾向は, $T$ $=1000$ (days) の場合になるとより顕著である.

\section{5.あとがき}

多くの荷重の作用を受ける多部材要素からなる“weakest-link” モデルタイプの静定構造物の信頼性解析を 確率過程論を用いて行った. その結果をまとめると次の よらである.

（1）多次元空間の場合の超過の理論を用いて, 荷重 および部材強度がともに任意の確率分布を有する確率過 程であるような一般的な場合の静定構造物の破壊確率の 算定式を誘導した。

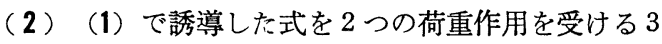
部材静定トラス構造物に適用し, 荷重および部材強岐が ともに正規定常確率過程で, 各部材の破壊事象の間の相 関性を考慮した場合の構造物の破壊確率の算定式を誘導 した.

（3）（2）で誘導した式において, 荷重作 用が単一 で, 構造物を構成するすべての部材の中央安全率, 部材 強度の変動係数, 部材強度の導関数に関するパラメータ 一, 各部材強度および部材力間の相関係数がすべて同一 であるとして式の簡略化を行った．また各部材の破壊事 象が統計的に独立であると考えると, その式は, 正規確 率積分を用いてさらに簡単化され, 容易に $n$ 部材静定卜 ラスの場合に拡張できることを示し，その場合の式を誘 導した.

（4）（2）および（3）で誘導した式を用いて数值計 算を行い, 多部材要素からなる静定構造物の破壊確率に およぼす構造物の耐用期間, 荷重および部材強度の変動 係数, 部材の中央安全率, 部材数および各部材間の破壊 に関する相関係数などの影響を明らかにした.すなわち 本論文で示したような確率過程論を用いて求めた破壊確 率の値の方が, 従来の静的信頼性理論による值よりも大 きくなり, その傾向は, 部材強度の変動係数, 構造物の 耐用期間, 部材の中央安全率および部材数が大きくなる ほど顕著であることがわかった．また部材強度の変動係
数の大きさにかかわらず，部材の 中央安全率が 2.0 以 上になると各部材の破壊事象の間の相関性を考慮しなく てもある程度の精度で破壊確率の算定が可能である.

本研究で取り扱った荷重は, 構造物の耐用期間を通じ て作用する荷重, すなわち長期的な変動をする荷重であ る.たとえば橋梁に作用する風や交通荷重, 海中構造物 に作用する波浪荷重などである。これらの荷重は単に 1 日とか 2 日間だけ作用するのではなくて, 構造物の使用 期間中（断続的ではあるにせよ）ずっと作用し続けるも のである.本論文ではこのような荷重を対象とし，これ らの不規則変動量の特性を期待值と相関関数とによって 特徵づけている.このような時間領域内で長期にわたっ て変動する荷重作用を受ける構造物の信頼性解析は（確 率変数論ではなくて）本論文に示したようは確率過程論 のたすけをかりてはじめて可能となる.

本研究にお污る数值計算には, 鳥取大学工学部計算機 センターの TOSBAC-3400/21 を使用した. 式 (31)の 数值積分に際しては, Lagurre-Gauss の多点法泉のうち の 26 点法を採用した.

最後に, 本研究を遂行するにあたり数值計算そのほか にご協力いただいた当研究室の大学院学生山根和弘君な らびに学部学生松岡和己君 (現在大阪大学大学院学生) に謝意を表わす次第である. なお，本研究の一部は昭和 51 年度の文部省科学研究費 (一般研 究 $\mathrm{C}$, 課題番号 155164）によった.

\section{【付録】 $p_{-}(0 \mid t)$ の誘導}

$n$ 次元空間において, ランダムベクトル $\boldsymbol{Z}(t)$ が許容 領域 $\Omega_{0}$ の境界 $\Gamma$ を外向きの法線方向で超過する確率 の時間密度 $p(\Gamma \mid t)$ は, 一次元空間の場合と同様な議論 を行うことによって, 次式で与えられる。

$$
p(\Gamma \mid t)=\lim _{\Delta t \rightarrow 0} \frac{P_{1}(\Gamma \mid t)}{\Delta t} \cdots \cdots \cdots \cdots \cdots \cdots \cdots \cdots(\mathrm{A} .1)
$$

ここに, $P_{1}(\Gamma \mid t)$ は，十分小さなインターバル $\Delta t$ の間 に, 表面 $\Gamma$ と過程 $\boldsymbol{Z}(t)$ とが内から外への交差を 1 回 行うという不規則事象の確率である. 式 (A.1) は, $\boldsymbol{Z}(t)$ とその第 1 次導関数 $\dot{\boldsymbol{Z}}(t)$ との間の結合確率密度 $f(z, \dot{z} \mid t)$ を用いて次式で示される (Fig. 12 参照).

$$
p(\Gamma \mid t)=\int_{\Gamma} d \Gamma \int_{\dot{z}_{n}>0} f\left(\boldsymbol{z}_{\Gamma}, \dot{z} \mid t\right) \dot{z}_{n} d \dot{\boldsymbol{z}}
$$

ここに

$$
\begin{aligned}
& z_{\Gamma}: \boldsymbol{Z}(t) \text { の境界面 } \Gamma \text { 上での值, } \\
& \dot{z}_{n}: \boldsymbol{Z}(t) \text { の第 } 1 \text { 次導関数の法線方向成分, 寸な } \\
& \quad \text { わち } \dot{z}_{n}(\dot{\boldsymbol{z}}, \boldsymbol{n}), \\
& \boldsymbol{n}: \text { 外向きの法線の単位ベクトル. }
\end{aligned}
$$


この式 (A.2) が文献 4) で示されている $n$ 次元空間で のランダムベクトル $\boldsymbol{Z}(t)$ が許容領域を内から外へ超過 する確率の時間密度である.

本論文では, ランダムベクトル $\boldsymbol{Z}(t)$ の正領域から負 領域への超過確率の時間密度 $p_{-}(0 \mid t)$ が必要である.し たがって, 式 (A.2) の積分で $\boldsymbol{Z}(t)$ の正領域から負領 域への超過の場合だけを取り出して成分表示すると, 本 文中の式（5）となる.

\section{参考 文献}

1) А.Р. Ржаницын : Определение коэффициента запаса при нагрузках, представляющих собой случайные процессы. Строительая механика и расчет асчет сооружений, No. 3 , pp. 7 11, 1971-6.

2) 中山隆弘: 不規則振動における first-passage probability について, 第 25 回土木学会中国四国支部学術講演会概要 集, 1975 , pp. $1 \sim 2$.

3）中山隆弘：不規則振動における first-passage probability
について, 土木学会第 30 回年次学術講演会概要集, pp. $611 \sim 612$.

4) В.В. Болотин : Применение методов теории вероятностей и теории надежности расчетах сооружений. Стройиздат, Москва, 1971, pp. 206 214.

5) Moses, F. and Kinser, D.E. : Analysis of Structural Reliability, Journal of the Structural Division, ASCE Vol. 93, No. ST 5, Oct., 1967, pp. 147 164.

6) Ang, H.-S.A. and Amin, M : Reliability of Structures and Structural Systems, Journal of the Engineering Mechanics Division, ASCE, Vol. 94, No. EM 2, Apr., 1968, pp. 671 691.

7) 高岡宣善 : 構造物の設計・安全性・信頼性, 土木学会誌, 第 61 巻第 3 号, pp. 33 41, 1976 年 3 月.

8) Moses, F. : Reliability of Structural Systems, Journal of the Structural Division, ASCE, Vol. 100, No. ST 9, Sept., 1974, pp. 1813 1820.

9）一松 信・宇野利雄・山口二郎共編 : 電子計算機のための 数值計算法III, 培風館, 1972 , pp. 302 308.

(1976.7.16 - 受付) 